\title{
Europe Must Rise to the Challenge
}

\section{Natalie Tocci}

\author{
Natalie Tocci \\ Istituto Affari Internazionali, Rome, Italy \\ Director \\ DOI: $10.31278 / 1810-6374-2020-18-2-62-64$
}

COVID-19 will most likely become a critical factor of our age. Not only because this global crisis will certainly have political, economic, and social repercussions reverberating across the world for years to come, but because its consequences may well accelerate the change, if not tip outright, the balance for a new international order.

It is already a fact that the world has exited the unipolar moment when the United States' hegemony dominated world affairs. It was a world embedded in a specific configuration of power sustained by a set of laws, rules, norms, and institutions that together made up a liberal international society. This system started fraying with the emergence of multiple centers of power, above all China, and the growth of rivalry between them.

This is the context in which COVID-19 emerged. It explains why the global pandemic can trigger an irreversible tipping point in the change of the international system. COVID-19 may well become the most important event of our time as it magnifies and accelerates the weakening of the U.S.'s global leadership and the liberal norms that were pivotal for building and sustaining the international system.

As for global leadership, China, originally the bete noire of the coronavirus, may end up as the victor in this global crisis, partly because it successfully coped with it at home by resorting to draconian lockdowns that Western countries, beginning with Italy, grudgingly but invariably followed. True, European countries closed in a manner attuned to their 

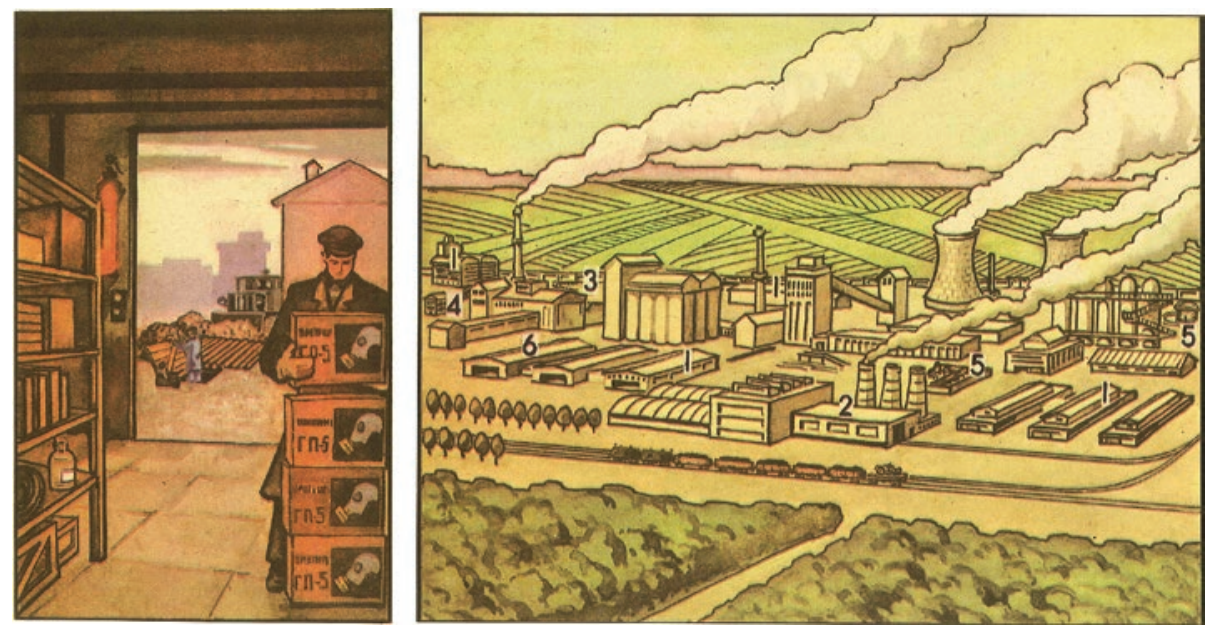

open political system. To limit contagion, they did not use massive physical control or manipulation of public information that we have seen in China, or extensive collection of data on citizens that could eventually be used for other purposes as well. However, we do not know whether Western countries' "democratic closure" will prove as effective as China's "authoritarian" one. In any case, we have followed China's model, even though in our European way, rather than those of South Korea, Taiwan or Hong Kong.

Moreover, China's global role in the COVID-19 crisis has made the inadequacy of the U.S. global hegemony painfully obvious. Beijing's display of solidarity by sending plane- and shiploads of protective masks, testing kits, ventilators, respirators and medical staff, as well as its vast global outreach with offers of knowledge transfer, stands in stark contrast to Washington's disdain for a "foreign" virus, its unilateral ban on travel for people from its supposedly closest European allies, its inhuman tightening sanctions on coronavirus-infected Iran, and its embarrassing attempt to secure a possible German vaccine "exclusively for the United States." So far, China has been winning the propaganda war by a wide margin.

COVID-19 may well become the final nail in the coffin of a rules-based international order. But it may also give birth to a new phoenix rising from its ashes. Much will depend on how Europe, being at the epicenter of this epochal crisis, will confront it, both internally and internationally. Coming on the heels of the Eurozone and migration crises, COVID-19 represents yet 

another opportunity for the European project. The Union has always built itself on the ashes of crises, but it has also always done the bare minimum to pull through. This half-way turning of crisis into opportunity has been the leitmotif of the European project so far. This time it may be insufficient. As the coronavirus vindicates, exacerbates and accelerates many of the global trends that we have seen in slow-motion in recent years, Europe must rise to the challenge if it is truly determined to protect its citizens and the values of a rules-based multilateral system. 